\title{
Predictors of Social Physique Anxiety among Recreational Bodybuilders
}

\author{
Mirta Blažev \\ Ivo Pilar Institute of Social Sciences, Zagreb, Croatia \\ Divna Blažev, Anita Lauri Korajlija \\ University of Zagreb, Faculty of Humanities and Social Sciences, Zagreb, Croatia \\ Veronika Blažev \\ TDR d.o.o., Rovinj, Croatia
}

\begin{abstract}
This study aimed to determine the contribution of gender, age, intensity of exercise, perfectionism, perfectionistic self-presentation and eating attitudes in the explanation dimensions of social physique anxiety (SPA) in a sample of 345 male and female gym exercisers. The results of this study indicate that the implemented model explains $21.3 \%(p<.001)$ of the variance in Dissatisfaction with appearance and $48.4 \%(p<.001)$ of the variance in Worry about appearance. Significant predictors of Dissatisfaction with appearance are intensity of exercise, discrepancy and eating attitudes, while significant predictors of Worry about appearance are gender, intensity of exercise, discrepancy, avoiding displays of imperfection and eating attitudes. In other words, recreational levels of exercise, negative perfectionism and negative attitudes towards food are strong predictors of social physique anxiety, while the tendency to hide our imperfections and female gender are only relevant when it comes toWorry about appearance.
\end{abstract}

Keywords: perfectionism, perfectionistic self-presentation, social physique anxiety, eating disorders, bodybuilding

\section{Introduction}

Social physique anxiety reflects individual's worry over presenting their body in situations in which they consider themselves to be evaluated by others (Hagger \& Stevenson, 2010; Leary \& Kowalski, 1990) or anxiety related to a concern that their

Anita Lauri Korajlija, Department of Psychology, Faculty of Humanities and Social Sciences, University of Zagreb, I. Lučića 3, 10000 Zagreb, Croatia. E-mail: alauri@ffzg.hr 
body is negatively evaluated by others (Haase et al., 2002). Social physique anxiety and body dissatisfaction may be significant in the sporting context, where the conditions of exercise and sport place the physical body in the foreground. Namely, because the body is the centre of attention and exercise clothing itself is designed to give a strong visual impression of the body, exercising in such an environment contributes to increased body awareness (Katula et al., 1998) and accentuated social comparisons (Koyuncu et al., 2010). However, it is interesting to note that some studies have demonstrated that exercise and sports are associated with reduced social physique anxiety and less dissatisfaction with one's own body image (Hausenblas et al., 2004; Hurst et al., 2000; Mülazımoğlu-Ballı et al., 2010), while some research has suggested a connection between exercise and sports and elevated social physique anxiety (Sabiston et al., 2007), increased dissatisfaction with body image (Zabinski et al., 2001) and eating disorders (Eriksson et al., 2008; Höglund \& Normén, 2002; Sundgot-Borgen \& Torstveit, 2004).

Furthermore, it seems that focusing on exercise and one's own body can increase the probability of developing obsessive attitudes toward weight control (Adkins \& Keel, 2005; Davis \& Fox, 1993; Homan, 2010). Research has demonstrated that being excessively focused on body size and shape is the most significant psycho-social feature associated with the development of eating disorders in athletes (Griffiths et al., 2000; Homan, 2010; Stice 2002; Thompson \& Stice, 2001; Williamson et al., 1995). Namely, athletes whose physical appearance affects self-evaluation of performance are more often excessively concerned with body mass and body shape than athletes whose physical appearance does not affect performance evaluation and non-athletes (Krentz \& Warschburger, 2013; Schwarz et al., 2005; Smolak et al., 2000; Zucker et al., 1999). In addition, the prevalence of eating disorders is higher in sports that emphasize a lower percentage of body fat or a specific weight versus sports where this is less important (Chapman \& Woodman, 2015; Krentz \& Warschburger, 2011; Sundgot-Borgen \& Torstveit, 2004). Factors triggering eating disorders include a prolonged period of childhood, frequent weight changes, a sudden increase in training volume and traumatic events (e.g. injury, loss of coaches), all of which are very common in bodybuilding.

Bodybuilders in the competitive sphere are evaluated by the degree to which muscle mass, volume, definition and symmetry are developed. Bolin (1992) describes the competitive muscular form as a highly groomed and nutritionally profiled perfection that cannot be maintained and from which competitors necessarily diverge after the competition day. As such, this ideal represents a very short-lived moment of psychological satisfaction. Despite the unsustainability of competitive body forms, this ideal remains the standard against which bodybuilders estimate their body beyond the competition season.

Many bodybuilders strive towards achieving this aesthetic perfection not only because of its expected benefits but also because of the values it symbolizes - control, self-discipline, competence and sexual desirability (Blouin \& Goldfield, 1995). 
Considering the investment needed to change one's shape and weight in order to conform to low body fat standards, bodybuilders can be vulnerable to the development of unhealthy eating habits and weight control practices. Research show that bodybuilders exhibit a high level of perfectionism (Davis \& Scott-Robertson, 2000; Goldfield \& Woodside, 2009), body dissatisfaction (Blouin \& Goldfield, 1995; Goldfield \& Woodside, 2009; Mitchell et al., 2016), feelings of anxiety, depression and isolation, a preoccupation with body weight and shape (Andersen \& DiDomenico, 1992; Goldfield \& Woodside, 2009; Mitchell et al., 2016), reduced self-confidence (Blouin \& Goldfield, 1995; Goldfield \& Woodside, 2009) and a tendency towards unhealthy methods of physical modification (e.g. strict diet and dehydration methods) (Andersen et al., 1998; Goldfield, 2009; Goldfield et al., 1998).

Based on the research, it is evident that negative aspects of perfectionism can lead to a number of difficulties for bodybuilders. The extreme form of perfectionist self-presentation might be relevant to research in sports, where athletes with a tendency to be excessively focused on presenting an image of perfection to other people might be at risk for various negative outcomes (Flett \& Hewitt, 2005). For example, athletes who are overly focused on perfectionist self-presentation would be expected to be highly self-conscious and anxious individuals, overwhelmed by public appearance and body image (Flett \& Hewitt, 2005; Mitchell et al., 2016). In such cases, some might try to meet their needs for perfectionist self-presentation through behaviour such as compulsive exercise, which is also related to dimensions of perfectionistic self-presentation, such as perfectionistic self-promotion and nondisplay or nondisclosure of imperfections (Flett \& Hewitt, 2005; Flett et al., 1995). Previous studies have found a positive correlation between compulsive exercise and dimensions of perfectionism, such as high standards, discrepancy and order, among individuals with anorexia, bulimia, male bodybuilders and students (Davis \& Scott-Robertson, 2000; Goldfield, 2009; McLaren et al., 2001), suggesting that individual differences in perfectionist self-presentation play a more pernicious role in exercise behaviour and excessive aspirations than the dimension of perfectionism itself.

From the above, it seems reasonable to conclude that bodybuilders are potentially sensitive to exhibiting fear of a negative evaluation of appearance and to the development of eating disorders. Despite numerous studies examining perfectionism, perfectionist self-presentation, social physique anxiety and eating disorders among bodybuilders, the relationships between these constructs have not yet been explored. This study aimed to determine the degree to which gender, age, intensity of gym exercise, perfectionism, perfectionistic self-presentation and attitudes towards nutrition contribute to the explanation of social physique anxiety. We expect that greater social physique anxiety will be found among women, persons more serious about exercise and those more pronounced on dimensions of 
perfectionism and perfectionistic self-presentation as well as those with distorted attitudes towards eating.

\section{Method}

\section{Participants}

The present study included 345 participants, most of whom were male $(67 \%)$. The average age of participants was $M=27.3$ years ( $S D=6.46$, range 15-52 years). Table 1 presents the various socio-demographic and other characteristics of the examined sample.

Table 1

Distribution of Participants Across Socio-Demographic and Other Characteristics $(N=345)$

\begin{tabular}{llrr}
\hline & & \multicolumn{1}{c}{$\%$} \\
\hline \multirow{2}{*}{ Gender } & Male & 231 & 67.0 \\
& Female & 114 & 33.0 \\
\hline \multirow{3}{*}{ Highest level of } & Elementary school & 1 & 0.3 \\
education & High School & 131 & 38.0 \\
& Community College and College & 178 & 51.6 \\
& Master's Degree and Doctorate & 35 & 10.1 \\
\hline \multirow{4}{*}{ Work Activity } & Unemployed & 41 & 11.9 \\
& Student & 118 & 34.2 \\
& Employed & 185 & 53.6 \\
& Retired & 1 & 0.3 \\
\hline \multirow{3}{*}{ Time length of } & Up to 6 months & 30 & 8.7 \\
exercise in a gym & From 6 to 12 months & 25 & 7.2 \\
& From 12 to 24 months & 39 & 11.3 \\
& More than 24 months & 251 & 72.8 \\
\hline \multirow{4}{*}{ Type of workout } & professional program & 150 & 43.5 \\
in a gym & Individual training in a gym according to a & & \\
& professional program & 164 & 47.5 \\
& Training in a gym with a personal trainer & & \\
\hline \multirow{3}{*}{ Main goal of } & Reducing weight & 31 & 9.0 \\
\hline exercise & Improving health & 40 & 11.6 \\
& Developing muscle mass & 48 & 13.9 \\
& Meeting new people/socializing/fun & 150 & 43.5 \\
& Increasing endurance and/or strength & 2 & 0.6 \\
Frequency of & Up to 4 hours per week & 105 & 30.4 \\
\hline workout & 4 to 7 hours per week & 52 & 15.1 \\
& More than 7 hours per week & 159 & 46.1 \\
& & 134 & 38.8 \\
\hline
\end{tabular}


Blažev, M., Blažev, D., Lauri Korajlija, A., Blažev, V.:

Social Physique Anxiety among Bodybuilders

\begin{tabular}{llrr}
\hline & & $f$ & $\%$ \\
\hline Degree of & Recreational athlete & 88 & 25.5 \\
intensity of & Serious recreational athlete & 193 & 55.9 \\
exercise & Competitive athlete & 64 & 18.6 \\
\hline \multirow{3}{*}{ Self-assessed } & Extremely below average & 4 & 1.2 \\
physical & Below average & 11 & 3.2 \\
preparedness & Average & 99 & 28.7 \\
& Above average & 194 & 56.2 \\
& Extremely above average & 37 & 10.7 \\
\hline
\end{tabular}

Most participants hold a college or community college degree, and most of them are employed. When it comes to working out, most participants report having been frequenting a gym for more than 24 months, exercise at the gym for 4 to 7 hours per week and predominantly work out individually, with or without use of a professional program. For most participants, the main goal of exercising is developing muscle mass. Most participants rate their workout as serious recreation and consider themselves to be in above average physical shape.

\section{Measures}

The Almost Perfect Scale-Revised (APS-R, Slaney et al., 2001) is intended for the measurement of adaptive and non-adaptive dimensions of perfectionism. The APS-R consists of 23 items that are divided into three subscales: (1) the High standards subscale consists of 7 items that measure high personal standards and performance expectations (e.g. I have high expectations for myself); (2) the Order subscale consists of 4 items and measures individual preferences for order and organization (e.g. I am a neat person); and (3) the Discrepancy subscale has 12 items and measures negative features of perfectionism in which there arises a disparity between personal standards and perceived competence (e.g. I rarely meet my high standards). In completing the APS-R, participants responded by indicating their agreement to each of the 23 statements using a 7-point scale ranging from 1 (Strongly disagree) to 7 (Strongly agree). A higher score indicates more pronounced characteristics in each of the individual subscales. In this study, reliability measured by Cronbach alpha is: $\alpha=.79$ for the High Standards subscale, $\alpha=.87$ for the Order subscale and $\alpha=.89$ for the Discrepancy subscale.

The Perfectionistic Self-Presentation Scale (PSPS, Hewitt et al., 2003) is a 27item measure of an individual's need to publicly display his or her perfection. It consists of three subscales: Perfectionistic self-promotion (10 items; It is very important that I always appear to be on top of things), Nondisplay of imperfection (10 items; I do not want people to see me do something unless I am very good at it) and Nondisclosure of imperfection (7 items; Admitting failure to others is the worst possible thing). Respondents rate their agreement with each statement on a 7-point Likert scale ranging from 1 (Strongly disagree) to 7 (Strongly agree). Results are 
formulated as a linear combination for each subscale independently, while higher score indicates greater expression of a particular dimension. The Cronbach alpha values are .87 for the Perfectionistic self-promotion subscale; .87 for the Nondisplay of imperfection subscale and .72 for the Nondisclosure of imperfection subscale.

The Social Physique Anxiety Scale (SPAS, Hart et al., 1989) is a tool for measuring worry related to beliefs that one is being negatively evaluated by others based on the appearance. The SPAS is a self-assessment questionnaire in which participants respond to 12 statements using a 5-point scale $(1=$ Not at all characteristic of me, $5=$ Extremely characteristic of me). Because statements are in both positive and negative directions, the total score is calculated as the sum of all negatively worded statements and reverse scoring of the positively worded statements. A higher score indicates higher social physique anxiety.

Research has demonstrated satisfactory validity and reliability for the SPAS (Hart et al., 1989). However, because the SPAS demonstrated unsatisfactory internal consistency $(\alpha=.42)$ in a Croatian sample, a modified scale was constructed (Lauri Korajlija et al., 2017). The Dissatisfaction with appearance subscale consists of 3 items and measures the degree to which a person is dissatisfied with the form and shape of their body (e.g. When I look in the mirror I feel good about my physique or figure). The Worry about appearance subscale has 7 items and measures concern with how others evaluate the individual's body shape and form (e.g. When in a bathing suit, I often feel nervous about how well-proportioned my body is). The Cronbach alpha reliability coefficients have shown satisfactory reliability on both dimensions: $\alpha=.88$ for the Worry about appearance subscale and $\alpha=.80$ for the Dissatisfaction with appearance subscale.

The Disordered Eating Attitude Scale (DEAS, Alvarenga et al., 2013) measure beliefs, thoughts, feelings, behaviours, and relationships towards food. It is intended for both clinical and non-clinical populations and consists of 25 questions (question 1 has additional a, b, c parts) divided into two parts. The first part of the questionnaire includes 12 questions concerning eating habits and the assessment of healthy food. In first question participants evaluate the degree to which 13 food items (e.g. Sugar, French fries, Oil, Bread, Rice, Beans, Pasta, Red meat, Whole milk, Cheese, Vegetables, Fruits and White meat) are considered to be healthy and necessary in their diet ( $1=$ Eating this food often is healthy and necessary; $3=$ Eating this food occasionally is healthy and necessary; 5 = Not eating this food is healthy and necessary), with higher score indicating distorted assessment of healty food. In remaining 11 questions participants answer "Yes" or "No" to questions concerning their eating habits (e.g. Do you "skip" meals to avoid putting on weight?), and are scored with 1 or 5 , with higher score indicating bad eating habits. The second part of the questionnaire involves the evaluation of eating attitudes with 13 questions (e.g. I feel guilty when I eat something that I thought I should not eat for some reason) on a 5-point scale $(1=$ Always; $5=$ Rarely/never $)$. The theoretical range of results is 
from 37 to 185, with higher scores indicating more highly negative attitudes towards eating. The reliability of the total scores is $\alpha=.78$.

\section{Procedure}

For the purposes of conducting the present study, an online questionnaire was created on "Survey Monkey". The questionnaire was forwarded to participants together with a short letter emphasizing the voluntary and anonymous nature of participation in the research. Questionnaire distribution was completed via social networks and online forums related to working out in gyms, where recreational athletes and competitive bodybuilders share experience and knowledge with each other (e.g. Forum Teretana, FC XXL, FC JUMP).

\section{Results}

Table 2 presents descriptive data for all measured variables of social physique anxiety (Dissatisfaction with appearance and Worry about appearance), perfectionistic self-presentation (Perfectionistic self-promotion, Nondisplay of imperfection, Nondisclosure of imperfection), perfectionism (High standards, Order, Discrepancy) and eating attitudes (DEAS) as well as the values of the KolmogorovSmirnov test for normality of distribution.

Table 2

Descriptive Data and Kolmogorov Smirnov Test for Dimensions of Social Physique Anxiety, Perfectionistic Self-Presentation, Perfectionism and Eating Attitudes $(N=345)$

\begin{tabular}{lcccccccc}
\hline & $M$ & $M d n$ & $S D$ & Min & Max & Skew. & Kurt. & $z$ \\
\hline $\begin{array}{l}\text { Dissatisfaction } \\
\text { with appearance }\end{array}$ & 7.6 & 7 & 2.68 & 3 & 15 & 0.46 & -0.16 & $0.13^{* *}$ \\
$\begin{array}{l}\text { Worry about } \\
\text { appearance }\end{array}$ & 16.6 & 15 & 6.90 & 7 & 35 & 0.59 & -0.50 & $0.11^{* *}$ \\
$\begin{array}{l}\text { Perfectionistic } \\
\text { self-promotion }\end{array}$ & 37.6 & 38 & 11.89 & 10 & 70 & 0.15 & -0.48 & 0.05 \\
$\begin{array}{l}\text { Nondisplay of } \\
\text { imperfection }\end{array}$ & 36.7 & 36 & 12.70 & 10 & 70 & 0.01 & -0.67 & $0.06^{*}$ \\
$\begin{array}{l}\text { Nondisclosure } \\
\text { of imperfection }\end{array}$ & 22.1 & 22 & 7.05 & 7 & 46 & 0.42 & 0.25 & $0.06^{* *}$ \\
$\begin{array}{l}\text { Discrepancy } \\
\text { Order }\end{array}$ & 42.2 & 41 & 14.98 & 14 & 79 & 0.25 & -0.77 & $0.07^{* *}$ \\
$\begin{array}{l}\text { High standards } \\
\text { DEAS }\end{array}$ & 22.1 & 23 & 4.57 & 8 & 28 & -0.78 & 0.05 & $0.12^{* *}$ \\
\hline
\end{tabular}

Note. Skew. $=$ Skewness; Kurt. $=$ Kurtosis; ${ }^{*} p<.05,{ }^{*} p<.01$. 
From the data presented in Table 2, it is evident that the distribution of results on all variables, apart from Perfectionistic self-promotion $(p=.08)$, deviates from normal $(p<.05)$. The Dissatisfaction with appearance, Worry about appearance, Nondisplay of imperfection, Nondisclosure of imperfection, Discrepancy and DEAS variables all have a positive asymmetric distribution, while Order and High standards variables have a negative asymmetric distribution.

However, given the absence of extreme deviations in the curvature and symmetry of distributions (Kline, 2005), the necessary pre-requisite of a normal distribution for parametric statistics can be considered to have been met.

In order to determine which variable clusters - (1) gender and age, (2) intensity of exercise, (3) dimensions of perfectionism, (4) dimensions of perfectionistic selfpresentation and (5) eating attitudes - explain the variance in dimensions of social physique anxiety (Dissatisfaction with appearance and Worry about appearance), two hierarchical regression analyses were performed. The results of this analysis are presented in Tables 4 and 5, while the correlations between all variables are presented in Table 3.

Table 3

Interrelationship Between Predictors (Age, Gender, Intensity of Exercise, Dimensions of Perfectionism and Perfectionistic Self-Presentation, Eating Attitudes) and Criterion (Dissatisfaction with Appearance and Worry About Appearance) $(N=345)$

\begin{tabular}{|c|c|c|c|c|c|c|c|c|c|c|}
\hline & 1 & 2 & 3 & 4 & 5 & 6 & 7 & 8 & 9 & 10 \\
\hline DWA & -.03 & .08 & $-.31^{* *}$ & $-.11^{*}$ & $.23^{* *}$ & -.07 & .06 & $.16^{* *}$ & $.14^{*}$ & $.28^{* *}$ \\
\hline WAA & -.10 & $.30^{* *}$ & $-.22^{* *}$ & -.01 & $.44^{* *}$ & .06 & $.36^{* *}$ & $.49^{* *}$ & $.28^{* *}$ & $.51^{* * *}$ \\
\hline 1 Age & & $.11^{*}$ & .04 & -.03 & -.05 & .06 & $-.17^{* *}$ & $-.15^{* *}$ & $-.17^{* *}$ & $-.12^{*}$ \\
\hline 2 Gender & & & $-.15^{* *}$ & .02 & .09 & .04 & -.07 & .02 & -.06 & $.19^{* * *}$ \\
\hline 3 Intensity & & & & $.21^{* * *}$ & .07 & $.14^{*}$ & .06 & -.04 & .04 & -.05 \\
\hline 4 High standards & & & & & $.16^{* *}$ & $.45^{* *}$ & $.24^{* *}$ & .04 & .07 & .10 \\
\hline 5 Discrepancy & & & & & & .08 & $.27^{* * *}$ & $.45^{* *}$ & $.35^{* *}$ & $.33^{* *}$ \\
\hline 6 Order & & & & & & & $.17^{* *}$ & .05 & .03 & .08 \\
\hline $\begin{array}{l}7 \text { Perfectionistic } \\
\text { self-promotion }\end{array}$ & & & & & & & & $.76^{* *}$ & $.65^{* *}$ & $.38^{* *}$ \\
\hline $\begin{array}{l}8 \text { Nondisplay of } \\
\text { imperfection }\end{array}$ & & & & & & & & & $.66^{* *}$ & $.36^{* *}$ \\
\hline $\begin{array}{l}9 \text { Nondisclosure } \\
\text { of imperfection }\end{array}$ & & & & & & & & & & $.26^{* *}$ \\
\hline 10 DEAS & & & & & & & & & & - \\
\hline
\end{tabular}

Note. DWA = Dissatisfaction with appearance; WAA = Worry about appearance $;{ }^{*} p<.05,{ }^{* *} p<.01$.

The data presented in Table 3 demonstrates that Dissatisfaction with appearance has low negative correlations with intensity of exercise and high standards and low positive correlations with DEAS, Discrepancy, Nondisplay of imperfection and Nondisclosure of imperfection. These correlations are all statistically significant. In contrast, age $(p=.56)$, Perfectionistic self-promotion $(p=.31)$, Order $(p=.22)$ and 
gender $(p=.16)$ variables are not statistically significantly related to Dissatisfaction with appearance.

The statistically significant but low positive correlations with Worry about appearance indicate that Perfectionistic self-promotion, gender, Nondisclosure of imperfection, DEAS, Nondisplay of imperfection and Discrepancy are associated with Worry about appearance, while intensity of exercise is statistically significantly, but negatively related to Worry about appearance. High standards $(p=.89)$, Order $(p$ $=.28)$ and age $(p=.06)$ were not statistically significantly related to Worry about appearance.

Table 4

Hierarchical Multiple Regression Predicting Dissatisfaction with Appearance $(N=345)$

\begin{tabular}{|c|c|c|c|c|c|c|c|c|c|c|c|}
\hline \multirow{2}{*}{ Step } & & \multicolumn{2}{|c|}{ Step 1} & \multicolumn{2}{|c|}{ Step 2} & \multicolumn{2}{|c|}{ Step 3} & \multicolumn{2}{|c|}{ Step 4} & \multicolumn{2}{|c|}{ Step 5} \\
\hline & & $\beta$ & $p$ & $\beta$ & $p$ & $\beta$ & $p$ & $\beta$ & $p$ & $\beta$ & $p$ \\
\hline & Age & -.04 & .46 & -.02 & 67 & -.01 & .87 & .001 & .98 & .02 & .69 \\
\hline & Gender $^{\mathrm{b}}$ & .08 & .14 & .03 & .53 & .01 & .85 & .01 & .79 & -.03 & .53 \\
\hline 2 & $\begin{array}{l}\text { Intensity of } \\
\text { exercise }\end{array}$ & & & -.30 & $<.001$ & -.30 & $<.001$ & -.30 & $<.001$ & -.29 & $<.001$ \\
\hline \multirow[t]{3}{*}{3} & High standards & & & & & -.09 & .11 & -.08 & .16 & -.08 & .19 \\
\hline & Discrepancy & & & & & .27 & $<.001$ & .24 & $<.001$ & .18 & $<.001$ \\
\hline & Order & & & & & -.01 & .94 & -.01 & .96 & -.01 & .88 \\
\hline \multirow[t]{3}{*}{4} & $\begin{array}{l}\text { Perfectionistic } \\
\text { self-promotion }\end{array}$ & & & & & & & -.04 & .67 & -.13 & .16 \\
\hline & $\begin{array}{l}\text { Nondisplay of } \\
\text { imperfection }\end{array}$ & & & & & & & .02 & .85 & .02 & .84 \\
\hline & $\begin{array}{l}\text { Nondisclosure of } \\
\text { imperfection }\end{array}$ & & & & & & & .09 & .21 & .10 & .14 \\
\hline \multirow[t]{2}{*}{5} & DEAS & & & & & & & & & .24 & $<.001$ \\
\hline & & \multicolumn{2}{|c|}{$R^{2}=.01$} & \multicolumn{2}{|c|}{$\begin{array}{c}R^{2}=.09 \\
\Delta R^{2}=.09\end{array}$} & \multicolumn{2}{|c|}{$\begin{array}{c}R^{2}=.17 \\
\Delta R^{2}=.07\end{array}$} & \multicolumn{2}{|c|}{$\begin{array}{c}R^{2}=.17 \\
\Delta R^{2}=01\end{array}$} & $\begin{array}{c}R^{2} \\
\Delta R \\
p\end{array}$ & $\begin{array}{l}.21 \\
=.04 \\
001 \\
\end{array}$ \\
\hline
\end{tabular}

Note. Step 1: Socio-demographic characteristics; Step 2: Exercise habits; Step 3: Dimensions of perfectionism; Step 4: Dimensions of perfectionistic self-presentation; Step 5: Eating attitudes; ${ }^{\text {b Gender }}$ is coded $1=$ male, $2=$ female. Coefficients significant at $5 \%$ level are typed in boldface.

Results demonstrate that this model, containing five clusters of predictors (gender and age, intensity of exercise, dimensions of perfectionism, dimensions of perfectionistic self-presentation and eating attitudes) explains $21.3 \%$ of the variance in Dissatisfaction with appearance. Significant predictors of Dissatisfaction with appearance are intensity of exercise $\left(R^{2}=.09, p<.001\right)$, dimensions of perfectionism $\left(R^{2}=.07, p<.001\right)$ and eating attitudes $\left(R^{2}=.04, p<.001\right)$. Gender and age $(p=.28)$ and dimensions of perfectionistic self-presentation $(p=.54)$ were not statistically significant predictors of Dissatisfaction with appearance. 
Together, these results demonstrate that statistically significant predictors of Dissatisfaction with appearance are the intensity of exercise, Discrepancy and DEAS, where recreational levels of exercise, more negative eating attitudes and higher negative perfectionism are associated with greater Dissatisfaction with appearance.

Using the same set of predictors, a hierarchical regression analysis was also conducted in order to examine the variance in the Worry about appearance dimension (Table 5).

Table 5

Hierarchical Multiple Regression Predicting Worry About Appearance $(N=345)$

\begin{tabular}{|c|c|c|c|c|c|c|c|c|c|c|c|}
\hline \multirow{2}{*}{ Step } & & \multicolumn{2}{|c|}{ Step 1} & \multicolumn{2}{|c|}{ Step 2} & \multicolumn{2}{|c|}{ Step 3} & \multicolumn{2}{|c|}{ Step 4} & \multicolumn{2}{|c|}{ Step 5} \\
\hline & & $\beta$ & $p$ & $\beta$ & $p$ & $\beta$ & $p$ & $\beta$ & $p$ & $\beta$ & $p$ \\
\hline \multirow[t]{2}{*}{1} & Age & -.14 & .01 & -.13 & .01 & -.11 & .02 & -.06 & .17 & -.04 & .36 \\
\hline & Gender $^{\mathrm{b}}$ & .32 & $<.001$ & .29 & $<.001$ & .24 & $<.001$ & .25 & $<.001$ & .20 & $<.001$ \\
\hline 2 & $\begin{array}{l}\text { Intensity of } \\
\text { exercise }\end{array}$ & & & -.17 & .001 & -.20 & $<.001$ & -.19 & $<.001$ & -.17 & $<.001$ \\
\hline \multirow[t]{3}{*}{3} & High standards & & & & & -.08 & .12 & -.10 & .05 & -.09 & .06 \\
\hline & Discrepancy & & & & & .43 & $<.001$ & .31 & $<.001$ & .24 & $<.001$ \\
\hline & Order & & & & & .09 & .09 & .06 & .23 & .05 & .27 \\
\hline \multirow[t]{3}{*}{4} & $\begin{array}{l}\text { Perfectionistic } \\
\text { self-promotion }\end{array}$ & & & & & & & .18 & .01 & .08 & .29 \\
\hline & $\begin{array}{l}\text { Nondisplay of } \\
\text { imperfection }\end{array}$ & & & & & & & .25 & $<.001$ & .25 & $<.001$ \\
\hline & $\begin{array}{l}\text { Nondisclosure of } \\
\text { imperfection }\end{array}$ & & & & & & & -.10 & .10 & -.08 & .16 \\
\hline \multirow[t]{2}{*}{5} & DEAS & & & & & & & & & .29 & $<.001$ \\
\hline & & & $\begin{array}{l}. .11 \\
.001\end{array}$ & \multicolumn{2}{|c|}{$\begin{array}{c}R^{2}=.14 \\
\Delta R^{2}=.03\end{array}$} & \multicolumn{2}{|c|}{$\begin{array}{c}R^{2}=.32 \\
\Delta R^{2}=.19\end{array}$} & \multicolumn{2}{|c|}{$\begin{array}{c}R^{2}=.42 \\
\Delta R^{2}=.10\end{array}$} & \multicolumn{2}{|c|}{$\begin{array}{c}R^{2}=.48 \\
\Delta R^{2}=.06 \\
p<.001\end{array}$} \\
\hline
\end{tabular}

Note. Step 1: Socio-demographic characteristics; Step 2: Exercise habits; Step 3: Dimensions of perfectionism; Step 4: Dimensions of perfectionistic self-presentation; Step 5: Eating attitudes; ${ }^{\text {b Gender }}$ is coded $1=$ male, $2=$ female. Coefficients significant at $5 \%$ level are typed in boldface.

Hierarchical regression confirmed that the model (i.e. the entire set of five variable clusters - gender and age, intensity of exercise, dimensions of perfectionism, dimensions of perfectionistic self-presentation, eating attitudes) predicted $48.4 \%$ of the variance in Worry about appearance. While all predictor clusters were found to statistically significantly explain the variance in Worry about appearance, the third variable cluster (dimensions of perfectionism) represented the largest single contribution (19\%) to explaining this variance.

Further, the results indicate that DEAS $(p<.001)$, Nondisplay of imperfection $(p=.001)$, Discrepancy $(p<.001)$, gender $(p<.001)$ and intensity of exercise $(p<$ $.001)$ are statistically significant predictors of Worry about appearance. Together, 
these results demonstrate that recreational levels of exercise, more negative eating attitudes, higher negative perfectionism and higher tendencies to hide one's imperfections are associated with greater Worry about appearance. The Worry about appereance is higher in females.

\section{Discussion}

The present study aimed to identify predictors of social physique anxiety among recreational bodybuilders. We predicted that participants with a negative attitude towards food, more pronounced negative aspects of perfectionism and more pronounced perfectionist self-representation would demonstrate greater concern and dissatisfaction with appearance. We were also interested in examining how exercise intensity, as a variable related to exercise habits, contributes to explaining the expression of social physique anxiety.

The used model, representing a set of five predictor clusters (gender and age, intensity of exercise, dimensions of perfectionism, dimensions of perfectionistic selfpresentation, eating attitudes), explains $21.3 \%$ of the variance in Dissatisfaction with appearance and $48.4 \%$ of the variance in Worry about appearance. These findings are partially consistent with our expectations. However, given the previously confirmed correlations between various predictors from the model and social physique anxiety (Flett et al., 1995; Haase et al., 2002; Krane et al., 2001; Sabiston et al., 2005; Salovey \& Rodin, 1984; Tesser \& Campbell, 1982; Vanraalte et al., 1998; Woodman \& Steer, 2011), it would have been reasonable to expect that this set of predictors would contribute to the explanation of a high percentage of the variance of social physique anxiety. The results are as hypothesized when it comes to Worry about appearance, but we expected that selected predictors would explain higher percentage of variance of Dissatisfaction with appearance. As such, it might be argued that variance in Dissatisfaction with appearance is in fact predicted by another set of predictors. Specifically, Dissatisfaction with appearance might better be explained with self-esteem or characteristics and aims of the exercise. Different motivation for exercise (e.g. health, muscle gain, weight loss, endurance or strength, appearance, fun, meeting new people/socializing, etc.) or different number of exercising per week might better predict one's (dis)satisfaction with appearance because it is not so focused on the interpersonal aspect but rather on intrapersonal evaluation of appearance, in contrast to Worry about appearance that has more pronounced social dimension. Future research should focus on determining what these predictors are for persons who exercise at the gym.

The findings presented here are consistent with those of previous studies that have demonstrated that more experienced exercisers are more satisfied with their appearance and are therefore less concerned about their appearance due to a greater subjective probability of achieving desired outcomes (Vanraalte et al., 1998). Also, 
negative perfectionism has been demonstrated to be an important predictor of both dimensions of social physique anxiety, a finding also confirmed in previous research (Flett et al., 1995; Sabiston et al., 2005; Woodman \& Steer, 2011). Specifically, greater disagreement between current and desired physical states predicts higher levels of social physique anxiety, or greater Dissatisfaction with appearance and Worry about appearance. Furthermore, higher desire to hide imperfections from others is related to greater Worry about appearance. Indeed, bodybuilding is a sport in which the goal is to exhibit the perfect form, which increases the likelihood that individuals with a tendency towards hiding their imperfection will be more highly concerned about their looks when they feel they are not "perfect enough". The positive perfectionism failed to demonstrate its protective function when it comes to social physique anxiety.

More negative attitudes towards food were related to greater Worry about appearance, a result likely because individuals with distorted attitudes towards eating are generally more critical of their appearance due to the great personal importance placed on appearance (Eriksson et al., 2008; Sundgot-Borgen \& Torstveit, 2004). Finally, women more often demonstrated concern about their appearance, a finding consistent with expectations related to the greater social pressure placed on women concerning their appearance (Hagger \& Stevenson, 2010; Katula et al., 1998; Mülazımoğlu-Ballı et al., 2010). It is well-established that women are socially expected to be thin while men are expected to be muscular (Eriksson et al., 2008; Mülazımoğlu-Ballı et al., 2010; Peters \& Phelps, 2001; Zabinski et al., 2001). With the onset of puberty, women move away from this social ideal while men move closer to it. Arguably, this is likely to contribute to a greater concern about appearance among women.

While perfectionist self-presentation did not additionally explain the variance in Dissatisfaction with appearance, it did make an independent contribution in explaining variance in Worry about appearance. It seems that, among recreational bodybuilders, Dissatisfaction with appearance is a variable explained by negative perfectionism and that social aspects of perfectionism (in this case, the need to present oneself as perfect) are more significant when it comes to Worry about appearance. This is probably because dimension Worry about appearance is more focused on measuring social aspect (i.e. worries about appearance in front of others) that is similar to construct of perfectionistic self-presentation that also has this social dimension, while Dissatisfaction with appearance does not have this social context pronounced, rather, it is individual's dissatisfaction with the form and the shape of their own body, regardless of others.

A number of implications stem from the findings of the present study. First, it is possible to conclude that social physique anxiety is less of a risk for individuals who exercise at serious recreational or competitive levels than for those exercising at recreational levels. However, both dimensions of social physique anxiety Dissatisfaction with appearance and Worry about appearance - are likely to be more 
pronounced among maladaptive perfectionists. Likewise, Worry about appearance will be more pronounced in those who are inclined to avoid displaying their imperfection. These findings have important implications for the work of sports psychologists and coaches who, during the training process, should pay attention to maladaptive perfectionism and need to hide imperfections in order to avoid the pernicious role of these traits in the exercise behaviour and excessive aspirations of the exerciser. The results of this study also confirm the correlation between distorted attitudes towards food and social physique anxiety, which together can represent risk factors for the development of eating disorders among exercisers. Although a highly structured diet plan is typical for bodybuilders, it is important to pay attention to the possibility that it might conceal an underlying eating disorder. Additionally, sports psychologists or coaches should also be wary of the greater sensitivity among females to developing problems with social physique anxiety.

When discussing the obtained results, it is necessary to note the limitations related to the use of the SPAS questionnaire. Due to its unexpectedly low reliability, this questionnaire was divided into two dimensions (Dissatisfaction with appearance and Worry about appearance), thus significantly reducing the number of items measuring each desired dimension (Lauri Korajlija et al., 2017). As such, previous use of this tool is not consistent with the method used in the present research, where the questionnaire was divided into two dimensions and two items were removed. A second limitation to the present study arises concerning the suitability of the sample. Namely, because the sample represents a self-selected group of recreational bodybuilders that were initially attracted to the topic of the research, the overall representativeness of the findings is reduced. Specfically, it is not possible to determine whether participants were attracted to participate in the study because they had more or less social physique anxiety than those who chose not to participate. A final limitation of the present study stems from the very low reliability of the DEAS sub-scale. For this reason, only the overall result was used for this measure.

In conclusion, our results demonstrate that negative perfectionism and negative attitudes towards food are strong predictors of social physique anxiety, while the tendency to hide our imperfections and female gender are only relevant when it comes to Worry about appearance. In future research, it will be important to consider such differences in predicting Dissatisfaction with appearance and Worry about appereance. It might be argued that recreational bodybuilders can be satisfied with their appearance, but nevertheless constantly worried about appearance because of difficulties in maintaining a fit body shape (due to injury, demanding training regimes and strict food schedules). It is also important to consider the reasons for which positive perfectionism failed to demonstrate its expected protective value. 


\section{References}

Adkins, E. C., \& Keel, P. K. (2005). Does "excessive" or "compulsive" best describe exercise as a symptom of bulimia nervosa? International Journal of Eating Disorder, 38(1), 24-29.

Alvarenga dos Santos M., Carvalhom, P. H. B., Scagliusi, F. B., \& Philippi, S. T. (2013). Psychometric properties of the disordered eating attitude scale for adult men. Journal Brasileiro de Psiquiatria, 62(4), 253-260.

Andersen, R. E., Brownell, K. D., Morgan, G. D., \& Barrlett, S. J. (1998). Weight loss, psychological, and nutritional patterns in competitive female bodybuilders. Eating Disorders, 6, 159-167. https://doi:org/0.1080/10640269808251251

Andersen, A. E., \& DiDomenico, L. (1992). Diet vs. shape content of popular male and female magazines: A dose response relationship to the incidence of eating disorders? International Journal of Eating Disorders, 11, 283-287. https://doi.org/10.1002/1098108X(199204)11:3<282::AID-EAT2260110313>3.0.CO;2-0

Blouin, A. G., \& Goldfield, G. S. (1995). Body image and steroid use in male bodybuilders. International Journal of Eating Disorders, 18(2), 159-165. https://doi.org/10.1002/1098108X(199509)18:2<159::AID-EAT2260180208>3.0.CO;2-3

Bolin, A. (1992). Flex appeal, food, and fat: Competitive bodybuilding, gender, and diet. Play and Culture, 5, 378-400.

Chapman, J., \& Woodman, T. (2015). Disordered eating in male athletes: A meta-analysis. Journal of Sports Sciences, 34(2), 1-9. https://doi.org/10.1080/02640414.2015. 1040824

Davis, C., \& Fox, J. (1993). Excessive exercise and weight preoccupaton in women. Addict Behaviour, 18(2), 201-211.

Davis, C., \& Scott-Robertson, L. A. (2000). Psychological comparison of females with anorexia nervosa and competitive male bodybuilders: Body shape ideals in the extreme. Eating Behaviours, 1, 33-46. https://doi.org/10.1016/S1471-0153(00)00007-6

Eriksson, L., Baigi, A., Marklund, B., \& Lindgren, E. C. (2008). Social physique anxiety and sociocultural attitudes toward appearance impact on orthorexia test in fitness participants. Scandinavian Journal of Medicine \& Science in Sports, 18(3), 389-394.

Flett, G. L., \& Hewitt, P. L. (2005). The perils of perfectionism in sports and exercise. American Psychological Society, 14(1), 14-18. https://doi.org/10.1111/j.0963-7214.2005.00326.x

Flett, G. L., Hewitt, P. L., Endler, N. S., \& Tassone, C. (1995). Perfectionism components of state and trait anxiety. Current Psychology: Developmental, Learning, Personality, Social, 13(4), 326-350. https://doi.org/10.1007/BF02686891

Goldfield, G. S. (2009). Body image, sisordered eating and anabolic steroid use in female bodybuilders. Eating Disorders, 17, 200-210.

Goldfield, G. S., Harper, D. W., \& Blouin, A. G. (1998). Are bodybuilders at risk for eating disorders? Eating Disorders: The Journal of Treatment and Prevention, 17, 200-210. 
Goldfield, G. S., \& Woodside, B. (2009). Body image, disordered eating, and anabolic steroids in male bodybuilders: Current versus former users. The Physician and Sports Medicine, 1(37), 111-114.

Griffiths, R. A., Mallia-Blanco, R., Boesenberg, E., Ellis, C., Fischer, K., Taylor, M., \& Wyndham, J. (2000). Restrained eating and sociocultural attitudes to appearance and general dissatisfaction. European Eating Disorders Review, 8(5), 394-402. https://doi.org/10.1002/1099-0968(200010)8:5<394::AID-ERV358>3.0.CO;2-B

Haase, A. M., Prapavessis, H., \& Owens, R. G. (2002). Perfectionism, social physique anxiety and disordered eating: A comparison of male and female elite athletes. Psychology of Sport and Exercise, 3, 209-222. https://doi.org/10.1016/S1469-0292(01)00018-8

Hausenblas, H. A., Brewer, B., \& Vanraalte, J. L. (2004). Self-presentation and exercise. Journal of Applied Sport Psychology, 1, 3-18. https://doi.org/10.1080/10413200490260026

Hagger, M. S., \& Stevenson, A. (2010). Social physique anxiety and physical self-esteem: Gender and age effects. Psychology and Health, 25(1), 89-110. https://doi.org/10.1080/ 08870440903160990

Hart, E. A., Leary, M. R., \& Rejeski, W. J. (1989). The measurement of social physique anxiety. Journal of Sport and Exercise Psychology, 11, 94-104. https://doi.org/10.1123/ jsep.11.1.94

Hewitt, P. L., Flett, G. L., Sherry, S. B., Habke, M., Parkin, M., Lam, R. W., McMurtry, B., Ediger, E., Fairlie, P., \& Stein, M. B. (2003). The interpersonal expression of perfection: Perfectionistic self-presentation and psychological distress. Journal of Personality and Social Psychology, 84(6), 1303-1325. https://doi.org/10.1037/0022-3514.84.6.1303

Homan, K. (2010). Athletic-ideal and thin-ideal internalization as prospective predictors of body dissatisfaction, dieting, and compulsive exercise. Body Image, 7, 240-245. https://doi.org/10.1016/j.bodyim.2010.02.004

Höglund, K., \& Normén, L. (2002). A high exercise load is linked to pathological weight control behavior and eating disorders in female fitness instructors. Scandinavian Journal of Medicine and Science in Sports, 12(5), 261-275. https://doi.org/10.1034/j.16000838.2002.10323.x

Hurst, R., Hale, B., Smith, D., \& Collins, D. (2000). Exercise dependence, social physique anxiety, and social support in experienced and inexperienced bodybuilders and weightlifters. British Journal of Sports Medicine, 34(6), 431-435.

Katula, J. A., McAuley, E., Mihalko, S. L., \& Bane, S. M. (1998). Mirror, mirror on the wall... exercise environment influences on self-efficacy. Journal of Social Behavior and Personality, 13, 319-332.

Kline, R. B. (2005). Principles and practice of structural equation modeling. Guilford.

Koyuncu, M., Tok, S., Canpolat, A. M., \& Catikkas, F. (2010). Body image satisfaction and dissatisfaction, social physique anxiety, self-esteem, and body fat ratio in female exercisers and nonexercisers. Social Behaviour and Personality, 38(4), 561-570. https://doi.org/10.2224/sbp.2010.38.4.561 
Krane, V., Stiles-Shipley, J. A., Waldron, J., \& Michalenok, J. (2001). Relationships among body satisfaction, social physique anxiety, and eating behaviors in female athletes and exercisers. Journal of Sport Behavior, 24, 247-264.

Krentz, E. M., \& Warschburger, P. (2011). Sports-related correlates of disordered eating in athletic sports. Psychology of Sport and Exercise, 12(4), 375-382. https://doi.org/10. 1016/j.psychsport.2011.03.004

Krentz, E. M., \& Warschburger, P. (2013). A longitudinal investigation of sports-related risk factors for disordered eating in aesthetic sports. Scandinavian Journal of MedicineiScience in Sports, 23, 303-310. https://doi.org/10.1111/j.1600-0838. 2011.01380.x

Lauri Korajlija, A., Blažev, D., Blažev, M., \& Blažev, V. (2017). Social physique anxiety among bodybuilders. Collegium Antropologicum, 41(3), 247-255.

Leary, M. R., \& Kowalski, R. M. (1990). Impression management: A literature review and two component model. Psychological Bulletin, 107, 34- 47.

McLaren, L., Gauvin, L., \& White, D. (2001). The role of perfectionism and excessive commitment to exercise in explaining dietary restraint: Replication and extension. International Journal of Eating Disorders, 29, 307-313. https://doi.org/10.1002/eat.1023

Mitchell, L., Murray, S. B., Cobley, S, Hackett, D., Gifford, J., Capling, L., \& O’Connor, H. (2016). Muscle dysmorphia symptomatology and associated psychological features in bodybuilders and non-bodybuilder resistance trainers: A systematic review and metaanalysis. Sports Medicine, 47(2), 233-259. https://doi.org/10.1007/s40279-016-0564-3

Mülazımoğlu-Ballı, Ö., Koca, C., \& Aşçı, F. H. (2010). An examination of social physique anxiety with regard to sex and level of sport involvement. Journal of Human Kinetics, 26, 115-122. https://doi.org/10.2478/v10078-010-0055-9

Peters, M. A., \& Phelps, L. (2001). Body image dissatisfaction and distortion, steroid use, and sex differences in college age bodybuilders. Psychology in the Schools, 38(3), 283-289. https://doi.org/10.1002/pits.1018

Sabiston, C. M., Crocker, P. R. E., \& Munroe-Chandler, K. J. (2005). Examining currentideal discrepancy scores and exercise motivations as predictors of social physique anxiety in exercising females. Journal of Sport Behavior, 28, 68-85.

Sabiston, C. M., Sedgwick, W. A., Crocker, P. R. E., Kowalski, K. C., \& Mack, D. E. (2007). Social physique anxiety in adolescence: An exploration of influences, coping strategies, and health behaviors. Journal of Adolescent Research, 22(1), 78-101.

Salovey, P., \& Rodin, J. (1984). Some antecedents and consequences of social-comparison jealousy. Journal of Personality and Social Psychology, 47, 780-792. https://doi.org/10. 1037/0022-3514.47.4.780

Schwarz, H. C., Gairrett, R. L., Arguete, M. S., \& Gold, E. S. (2005). Eating attitudes, body dissatisfaction, and perfectionism in female college athletes. North American Journal of Psychology, 7(3), 345-352. 
Slaney, R. B., Rice, K. G., Mobley, M., Trippi, J., \& Ashby, J. S. (2001). The Revised Almost Perfect Scale. Measurement and Evaluation in Counseling and Development, 34(3), 130-145. https://doi.org/10.1037/t02161-000

Smolak, L., Murnen, S. K., \& Ruble, A. E. (2000). Female athletes and eating problems: A meta-analysis. International Journal of Eating Disorders, 27, 371-380. https://doi.org/10.1002/(SICI)1098-108X(200005)27:4<371::AID-EAT1>3.0.CO;2-Y

Stice, E. (2002). Risk and maintenance factors for eating pathology: A meta-analytic review. Psychological Bulletin, 128(5), 825-848. https://doi.org/10.1037/0033-2909.128.5.825

Sundgot-Borgen, J., \& Torstveit, M. K. (2004). Prevalence of eating disorders in elite athletes is higher than in the general population. Clinical Journal of Sport Medicine, 14(1), 25-32.

Tesser, A., \& Campbell, J. (1982). Self-evaluation maintenance and the perception of friends and strangers. Journal of Personality, 50, 261-279. https://doi.org/10.1111/j.14676494.1982.tb00750.x

Thompson, J. K., \& Stice, E. (2001). Thin ideal internalization mounting evidence for a new risk factor for body image disturbance and eating pathology. Current Direction in Psychological Science, 10(5), 181-183. https://doi.org/10.1111/1467-8721.00144

Vanraalte, J. L., Schmelzer, G. L., Smith, C. C., \& Brewer, B. W. (1998). Social physique anxiety in competitive women athletes. Journal of Gender, Culture, and Health, 3, 111-120.

Williamson, D. A., Netemeyer, R. G., Jackman, L. P., Anderson, D. A., Funsch, C. L., \& Rabalais, J. Y. (1995). Structural equation modeling of risk factors for the development of eating disorder symptoms in female athletes. International Journal of Eating Disorders, 17, 387-393. https://doi.org/10.1002/1098-108X(199595)17:4<387::AIDEAT2260170411>3.0.CO;2-M

Woodman, T., \& Steer, R. (2011). Body self-discrepancies and women's social physique anxiety: The moderating role of the feared body. British Journal of Psychology, 102, 147-160. https://doi.org/10.1348/000712610X507821

Zabinski, M. F., Calfas, K. J., Gehrman, C. A., Wilfley, D. E., \& Sallis, J. F. (2001). Effects of a physical activity intervention on body image in University seniors: Project GRAD. Annals of Behavioral Medicine, 23, 247-252. https://doi.org/10.1207/S15324796ABM2304_3

Zucker, N. L., Womble, L. G., Williamson, D. A., \& Perrin, L. A., (1999). Protective factors for eating disorders in female college athletes. Eating Disorders, 7, 207-218. https://doi.org/10.1080/10640269908249286 


\title{
Prediktori straha od negativne evaluacije izgleda među rekreativnim bodybuilderima
}

\begin{abstract}
Sažetak
Cilj je istraživanja bio utvrditi koliko spol, dob, ozbiljnost vježbanja, perfekcionizam, perfekcionistička samoprezentacija te stavovi prema hranjenju doprinose objašnjenju dimenzija straha od negativne evaluacije izgleda na uzorku od 345 muških i ženskih sudionika koji vježbaju u teretani. Rezultati istraživanja pokazuju da testirani model objašnjava $21.3 \%(p<.001)$ varijance Nezadovoljstva izgledom i $48.4 \%(p<.001)$ varijance Brige o izgledu. Značajni su prediktori Nezadovoljstva izgledom ozbiljnost vježbanja u teretani te Diskrepancija i stavovi prema hranjenju, dok su značajni prediktori Brige o izgledu spol, ozbiljnost vježbanja u teretani, Diskrepancija, nepokazivanje nesavršenosti i stavovi prema hranjenju. Drugim riječima, rekreativne razine vježbanja, neadaptivni perfekcionizam i negativni stavovi prema hranjenju snažni su prediktori straha od negativne evaluacije izgleda, dok su sklonost izbjegavanju pokazivanja vlastite nesavršenosti i ženski spol relevantni samo za Brigu o izgledu.
\end{abstract}

Ključne riječi: perfekcionizam, perfekcionistička samoprezentacija, strah od negativne evaluacije izgleda, poremećaji hranjenja, bodybuilding

Primljeno: 17. 11. 2019. 